\title{
Standards for Library and Information Services in Canadian Healthcare Facilities 2006
}

The following standards, with supporting evidence, are intended to serve as a guide to structuring library services within a health care facility.

\section{Acknowledgement}

The Canadian Health Libraries Association / Association des bibliothèques de la santé du Canada (CHLA/ABSC) gratefully acknowledges the Medical Library Association for granting permission to use the MLA publication Standards for Hospital Libraries 2002 with 2004 revisions [1].

\section{Introduction}

Efficient and timely access to evidence-based health literature is an important element in the provision of safe patient care. Given the complexity and time constraints involved in care delivery, locating the right information at the right time is increasingly difficult for many health practitioners. A strong Library and Information Service creates the bridge between the evidence and patient care decisions [2-4].

Information needs and library service are acknowledged in the standards of such accrediting organizations as the Canadian Council on Health Services Accreditation (CCHSA), the Liaison Committee on Medical Education (LCME), and the Royal College of Physicians and Surgeons of Canada Accreditation of Residency Programs.

Changing technologies, regionalization, computerization, and new approaches to health care have resulted in dramatic changes to healthcare facilities over the years, as evidenced in CCHSA's most recent Achieving Improved Measurement (AIM) standards (revised 2003). The 1995 CHLA Standards for Library and Information Services in Canadian Healthcare Facilities needed to be revised.

Before deciding to rewrite this set of standards using the substantially revised Medical Library Association's (MLA) 2002 standards as a model, the Task Force considered other library standards. The Australian Library and Information Association (ALIA) Guidelines for Australian Health Libraries 2000 are based significantly on Canadian 1995 Standards and are currently being revised but with the same structure and format. The Irish Health Sciences Librarians Group's Standards for Irish Healthcare Library and Information Services, 2nd 2005 edition were just released, also based extensively on the 1995 Canadian and Australian standards. However, the MLA Standards were chosen for their layout, clarity, and ease of use.

\section{Standard 1 Administration and Organization}

The Library and Information Service has its own budget and the health sciences librarian, as service/department manager, reports to senior management. The Library and Information Service is integral to developing systems and delivering services to meet the knowledge and evidence-based information needs of the organization and is a key collaborator in any information management initiative.

\section{Intent}

The Canadian Council on Health Services Accreditation Information Management Standard 5.3 requires that the organization make education and reference materials and research information available to staff, clients, and families, while Standard 5.4 requires that

- Systems must be in place to provide clear direction and timely access to education, reference and research materials that are evaluated against current and future needs

- A method for linking to relevant external databases, information networks and bodies of research knowledge must be provided

To meet these requirements, the Library and Information Service must be positioned to communicate with decision makers at the highest levels throughout the organization. Department status facilitates this process and enhances the library's ability to work with all areas within the hospital or health region.

\section{Standard 2 Management}

The Library and Information Service is managed by a professional librarian with a Master's degree in library and information science from an American Library Association (ALA) accredited university or recognized program.

\section{Intent}

A professional librarian has earned a Master's degree from a program that is accredited by the ALA or is recognized by either the ALA or an appropriate national body.

Competencies for professional librarians include an in-depth knowledge of print and electronic information resources, as well as the design and management of information services that meet the specific information needs of the individuals or groups being served [5-7]. 
The role of the professional librarian is to

- Provide reference and research services to support medicine, nursing, and allied health disciplines and administration

- Promote information literacy and client information skills development through formal and informal training

- Ensure client satisfaction by monitoring reference and research demands and evaluating library performance and quality indicators

- Ensure that library collections reflect the information needs of the changing health care environment

- Provide departmental strategy and direction

- Ensure that the work of the Library and Information Service reflects the strategic goals of the organization and that it is focused on effective and efficient service delivery

- Participate in strategic management initiatives

- Ensure client-centred service through the effective management of human resources

- Ensure compliance with external regulations

- Manage finances responsibly for staff, operations and capital

- Evaluate new information technologies and assess their implications for library services

- Negotiate license agreements for knowledge-based resources with vendors

\section{Standard 3 Staffing}

The Library and Information Service is staffed according to the MLA staffing formula of total institution FTE/700 [1]:

- If the result is less than or equal to $1 \mathrm{FTE}$, some $\%$ of the 1 FTE must be a professional librarian. The librarian may be through contract, outreach or a joint venture. Further explanation can be found in Appendix 1

- If the result is 1-3 FTE, then 1 FTE must be a professional librarian

- If the result is greater than 3 FTE, 33\% must be professional positions and the service/department manager must be a professional librarian [8]

The remaining percentages should be a mix of qualified library technicians, assistants, and clerks.

\section{Intent}

An under-staffed, under-skilled library cannot meet the knowledge-based information needs of an evidence-based environment. Demand for information is driven by the size and complexity of the institution as well as factors such as

- The number of medical residents, undergraduate medical students and other program interns at the facility

- The geographic size of the region and the extent of regionalization in an area. Fully integrated health region libraries provide services not only to acute care facilities, but also to long term and continuing care, community health and emergency medical services, often across broad geographic areas

The MLA formula provides an easy method to calculate staffing ratios. It is based on benchmarks across American and Canadian institutions [9].

For more detailed information on this standard, please refer to CHLA Fact Sheet: Human Resources Planning for the Health Facility Library, July 2005 (http://www.chlaabsc.ca/member/anterior/docs/fs23.pdf).

\section{Standard 4 Services}

The Librarian conducts an ongoing assessment of the information services needs of the organization and uses this assessment to develop and implement appropriate services to meet these needs and to maintain alignment with the organization's mission, vision, goals, and strategic plan.

Services must include

- Convenient access to expert searching

- Education on using electronic and print knowledge-based resources

- Training in evidence-based searching

- Appropriate technology to provide access to electronic resources

- A catalogue of resources that allows efficient access to and retrieval of materials

- Document delivery for materials not available in the libraries' print or electronic collections

\section{Intent}

Methods of delivering knowledge-based information are constantly changing. The Librarian must continually evaluate these new methods to ensure that the services offered by the library reflect the needs of the user groups.

\section{Standard 5 Resources}

The Library and Information Service provides knowledgebased resources that support all user information needs, including, but not limited to, patient care, education, administration, research, consumer health, and outreach programs. The Librarian uses a variety of tools and techniques, both formal and informal, to assess the knowledge-based resource needs of medical staff and health care personnel.

\section{Intent}

Resources are assessed through comparison with standard collection lists, reviews by experts in the field, other libraries' collections, and user surveys.

\section{Guideline}

Resources may include

- Current authoritative collections of print, electronic, and multimedia resources that support the timely provision of knowledge based information

- Resource sharing agreements and/or membership in library and information consortia that enable the efficient provision of materials not available on-site

\section{Standard 6 Promotion}

The Library and Information Service actively promotes knowledge-based information services to all primary client groups.

\section{Intent}

The Librarian publicizes services and resources to increase user awareness and encourage efficient use of the services 
and resources that are available. Effective library promotion educates users about databases and available resources and eliminates barriers, encouraging the increased use of evidencebased information in treatment decisions.

\section{Guideline}

Promotional programs and materials may include but are not limited to

Newsletters

Committee participation

Electronic bulletin boards

Library week/month celebrations

Open houses

Information booklets, brochures, and pathfinders

Presentations

Inclusion of library information in new staff, residents, and managers orientation

\section{Standard 7 Legislation and Compliance}

The Library and Information Service complies with relevant legislation, the CHLA/ABSC - MLA Code of Ethics (http://www.chla-absc.ca/assoc/chlawhat.html), and organizational policies, procedures, and standards.

\section{Standard 8 Accessibility}

Appropriate knowledge-based information resources are accessible 24 hours a day, 7 days a week.

\section{Intent}

As clinical decisions are often made outside of normal working hours, knowledge-based information resources must be accessible at all times. Depending upon the size and complexity of the institution, this may mean

- Resources are available through the organization's intranet or Internet

- Mechanisms are in place for after-hours library access

\section{Standard 9 Environment}

The Library and Information Service has an appropriate environment for delivering knowledge-based information. Physical space accommodates current and future (three to five years) requirements, for networked computers, print collections, staff workspaces, as well as areas for quiet study and group meetings [10]. Facilities for instruction and workshops are available for use by library services.

\section{Intent}

Despite the amount of information currently delivered electronically, "libraries will continue to provide group study spaces for individuals to engage in quiet pursuits and spaces for training in the use of information resources. Users demand spaces that are comfortable for thinking and working, are conducive to long periods of screen use, and have support systems and help in place, as well as quality output devices such as printers or high-definition screens. Browsing will be an essential function of libraries. A mix of group and individual study spaces, combined service points that assist users with both technology and the use of information resources, more emphasis on consumer health information, and more attractive spaces are all features" [11].

There are a variety of calculations that can be used to determine library space estimates. The MLA Guide to Managing Health Care Libraries provides an excellent table that summarizes the space formula options and other libraryspecific requirements such as floor loading [10].

\section{References}

1. Hassig RA, Balogh L, Bandy M, Doyle JD, Gluck JC, Lindner KL, et al. Standards for hospital libraries 2002 with 2004 revisions. J Med Libr Assoc. 2005 Apr;93(2):282-283.

2. Institute of Medicine. Committee on Quality of Health Care in America. Crossing the quality chasm : a new health system for the 21st century. Washington, D.C.: National Academy Press; 2001.

3. Summerskill W. Literature searches: look before you leap. Lancet. 2005 Jul 2-8;366(9479):13-14.

4. Williams L, Zipperer L. Improving access to information: librarians and nurses team up for patient safety. Nurs Econ. 2003 Jul-Aug;21(4):199-201.

5. Alliance of Libraries, Archives and Records Management. Competency Profile. Informaiton Resources Management specialists in Archives, Libraries and Records Management: A comprehensive Cross-Sectoral competency Analysis. 1999 April 1999.

6. Crosby O. Librarians: Information experts in the information age. OOQ. 2001(Winter 2000-01):2.

7. Medical Library Association. Medical Librarianship: A Career Beyond the Cutting Edge.

8. Creth SD, Duda F. Personnel administration in libraries. 2nd ed. New York: Neal-Schuman Publishers; 1989.

9. MLA Benchmarking Network. The composite hospital library: 2001 benchmarking aggregate data tables. 2002.

10. Holst R, Phillips SA, Bensing KM, Medical Library Association. The Medical Library Association guide to managing health care libraries. New York: Neal-Schuman Publishers; 2000.

11. Ludwig L, Starr S. Library as place: results of a delphi study. J Med Libr Assoc. 2005 Jul;93(3):315-326.

\section{Appendix 1}

Where the staffing formula results in less than 1 FTE, the services of a professional librarian may be obtained in the following manner:

- Contract Librarian: A written contractual arrangement may be negotiated with a Contract Librarian to provide ongoing direction and services at a level appropriate to client needs, facility programs and services, and the goals and objectives of the library.

- Circuit/Outreach Librarian: In some areas, larger healthcare facilities or academic libraries may offer the services of a circuit/outreach librarian. The circuit/outreach librarian makes regularly scheduled visits to the healthcare facility to provide information search and retrieval services and ensures that the available on site resources and services will effectively meet client needs.

- Joint Venture/Multi-Facility Arrangement: The services of a librarian, as well as the mandate for the provision of information resources, may be shared among facilities through a joint venture or other multi-facility arrangement. 


\section{Appendix 2 Glossary}

\section{Circuit/Outreach Librarian}

A professional librarian who provides services on a fixed schedule to more than one small healthcare facility library. This librarian may use the collection and services of a larger health sciences library in serving these libraries.

\section{Circulation}

Library functions pertaining to lending materials for use outside the library.

\section{Client}

Any individual/library receiving service from Library and Information Services. Clients may be internal or external to the facility.

\section{Consortia}

A group of libraries that have formally agreed to the cooperative sharing of resources.

\section{Core collection}

A minimal collection of current and authoritative information resources in any given field or for a particular type of library.

\section{Current awareness}

Services designed to keep clients up to date on new developments and materials published in their fields of interest.

\section{Document delivery}

Provision of library and information resources requested by clients. Document delivery may include circulation, photocopy services and interlibrary loans.

\section{Information literacy}

Information literacy is the ability to recognize when information is needed and to locate, evaluate and use effectively the needed information.

\section{Interlibrary loan}

Interlibrary loan is a mechanism for borrowing or lending original materials between cooperating libraries.

\section{Knowledge-based information}

KBI includes systems, resources and services to help health professional acquire the knowledge and skills needed to maintain and improve competence, to support clinical, managerial and business decision making, to support performance improvement and activities to reduce risk to patients, and to satisfy research needs.

\section{Library}

A comprehensive selection of services and resources, that are tailored to meet the information needs of a specific user group, organized for ease of access and under the direction of a professional librarian.

\section{Needs assessment}

A systematic process designed to determine the need for specific services or types of information by the library's user group. This may take the form of surveys, focus groups, and interviews.

\section{Professional Librarian}

A professional librarian has earned a Master's degree from a program that is accredited by the American Library Association (ALA) or recognized by the ALA or an appropriate national body.

\section{Appendix 3 Recommended Reading}

\section{Administration and Organization}

Eagleton KM. Quality assurance in Canadian hospital libraries the challenge of the eighties. Health Libr Rev. 1988;5:145.

Forsman RB. Administration and management in health sciences libraries. Lanham, Md.: Medical Library Association and the Scarecrow Press; 2000.

Holst R, Phillips SA, Bensing KM, Medical Library Association. The Medical Library Association guide to managing health care libraries. New York: Neal-Schuman Publishers; 2000.

\section{Impact}

Burton JE. The impact of medical libraries and literature on patient care in New Zealand. Bull Med Libr Assoc. 1995 Oct;83(4):425-430.

Freeth DS, Weist A, Roberts CM. Provision of an electronic library at the clinical frontline: evaluation of impact on hospital medical staff. Hosp Med. 2001 Jan;62(1):43-45.

Haynes RB, McKibbon KA, Walker CJ, Ryan N, Fitzgerald D, Ramsden MF. Online access to MEDLINE in clinical settings. A study of use and usefulness. Ann Intern Med. 1990 Jan 1;112(1):78-84.

Klein MS, Ross FV, Adams DL, Gilbert CM. Effect of online literature searching on length of stay and patient care costs. Acad Med. 1994 Jun;69(6):489-495.

Marshall JG. The impact of the hospital library on clinical decision making: the Rochester study. Bull Med Libr Assoc. 1992 Apr;80(2):169-178.

Moore ME, Garrison S, Hayes B, McLendon W. Reinventing a health sciences digital library — organizational impact. Med Ref Serv Q. 2003 Winter;22(4):75-82.

O'Connor P. Determining the impact of health library services on patient care: a review of the literature. Health Info Libr J. 2002 Mar;19(1):1-13.

Richwine MP, McGowan JJ. A rural virtual health sciences library project: research findings with implications for next generation library services. Bull Med Libr Assoc. 2001 Jan;89(1):37-44.

Sherwill-Navarro PJ, Wallace AL. Research on the value of medical library services: does it make an impact in the health care literature? J Med Libr Assoc. 2004 Jan;92(1):34-45.

Weightman AL, Williamson J, Library \& Knowledge Development Network (LKDN) Quality and Statistics Group. The value and impact of information provided through library services for patient care: a systematic review. Health Info Libr J. 2005 Mar;22(1):4-25.

Weightman A,L., Williamson J. The value and impact of information provided through library services for patient care: a systematic review. Health Information and Libraries Journal. 2005;22(1):4-25.

\section{Patient Safety}

Institute of Medicine. Committee on Quality of Health Care in America. Crossing the quality chasm : a new health system for 
the 21st century. Washington, D.C.: National Academy Press; 2001.

Ludwig L, Starr S. Library as place: results of a delphi study. J Med Libr Assoc. 2005 Jul;93(3):315-326.

Williams L, Zipperer L. Improving access to information: librarians and nurses team up for patient safety. Nurs Econ. 2003 JulAug;21(4):199-201.

Zipperer L. Clinicians, librarians and patient safety: opportunities for partnership. Qual Saf Health Care. 2004 Jun;13(3):218-222.

Zipperer L, Sykes J. The role of librarians in patient safety: gaps and strengths in the current culture. J Med Libr Assoc. 2004 Oct;92(4):498-500.

\section{Staffing}

Competency Profile. Information Resources Management specialists in Archives, Libraries and Records Management: A comprehensive Cross-Sectoral competency Analysis. 1999 April 1999.

Crosby O. Librarians: Information experts in the information age. OOQ. 2001(Winter 2000-01):2.

Medical Library Association. Medical Librarianship: A Career Beyond the Cutting Edge.

Stanley E. Competencies for hospital librarians. Natl Netw. 2000 Apr;24(4):12-3, 20.

\section{Standards}

Australia Library and Information Association. Guidelines for Australian Health Libraries. 2000; Available at http://www.alia.org.au/ policies/health.libraries.html. Accessed January 13, 2006.

Flower MA. Toward hospital library standards in Canada. Bull Med Libr Assoc. 1978 Jul;66(3):296-301.

Fowler C, Trinder V. Accreditation of Library and Information Services in the Health Sector. A Checklist to Support Assessment. Health Libraries and Information Confederation (HeLICon) Working Group. 2002; Available at http://www.nelh.nhs.uk/librarian/ Accreditation_Checklist_2nd_Edition_2002.pdf. Accessed January 13, 2006.

Hassig RA, Balogh L, Bandy M, Doyle JD, Gluck JC, Lindner KL, et al. Standards for hospital libraries 2002 with 2004 revisions. J Med Libr Assoc. 2005 Apr;93(2):282-283.

Lucey N. Standards for Irish Healthcare Library and Information Services. 2nd ed. Dublin, Ireland: Library Association of Ireland; 2005. Available at http://hrb.tinderbox.ie/archives/Standards_ cover.pdf. 